\title{
THE SPREAD OF MASSACHUSETTS LAW IN THE SEVENTEENTH CENTURY
}

\section{George L. Haskins $\dagger$ and Samuel E. Ewing, 3d $\ddagger$}

No history of the colonial period will be complete until the spread of ideas from colony to colony has been fully investigated. Intercolonial relations have received considerable attention, ${ }^{1}$ but the processes by which, and the extent to which, patterns of life and thought were carried from colony to colony still await detailed exploration.

A significant chapter in the history of those processes is the spread of legal ideas and institutions. One phase of that topic can be illumined by an investigation of the effect of the legislation of one colony upon that of others. Thus, it is clear that certain of the laws of Plymouth Colony were adopted by Massachusetts Bay, ${ }^{2}$ that certain laws of the latter colony found their way to Connecticut ${ }^{3}$ and eventually to New York, ${ }^{4}$ to New Jersey, ${ }^{5}$ to Delaware ${ }^{6}$ and to Pennsylvania. ${ }^{7}$ However, no attempt appears to have been made systematically to determine the precise extent of such intercolonial borrowing. It is the purpose of this paper to attempt to trace the provisions of the Massachusetts Code of 1648 which were adopted by the colonies of Connecticut and New Haven.

The Massachusetts Code of $1648^{8}$ was the product of several years of effort to reduce to writing the laws of Massachusetts Bay. ${ }^{9}$ When published, it was regarded as a complete statement of the laws, privi-

$\dot{T}$ Professor of Law, University of Pennsylvania Law School. LL.B., Harvard Law School, 1942. Member, Philadelphia Bar.

¥ LL.B., University of Pennsylvania Law School, 1955. Member, Chester County Bar.

1. E.g., 1 Osgood, The American Colonies in the Seventeenth Century 392$423(1904)$.

2. For example, divisible inheritance of land: Haskins, The Begimings of Partible Inheritance in the American Colonies, 51 YALE L.J. 1280, 1281 (1942); recording of deeds: Haskins, The Beginnings of the Recording System in Massachisetts, 21 B.U.L. REv. 281, 285 n.19 (1941).

3. See notes 18-23 infra.

4. Goebel \& Naughton, Law Enforcement in Colonial New York 16, 61 (1944) ; 1 COLONIAL LAWS OF NEW YORK 6-71 (1894).

5. See 23 New Jersey ARChIVES xiv-xv (1901).

6. E.g., 1 Delaware Body Laws 1700-1749, at 297, 298 (1752).

7. E.g., 1 Acts of Assembly of the Province of Peinnsylvania 33 (1775).

8. The Laws and Liberties of Massachuserts (Farrand ed. 1929).

9. These efforts are outlined in the MASSACHuserrs Colonial Laws 1660-1672 (Whitmore ed. 1889). 
leges, duties and rights in force in the jurisdiction, and, as such, it was the first comprehensive code of laws in the New World. ${ }^{10}$ That alone gives it special significance. But it derives added significance from the fact that many of its provisions were adopted by other New. England colonies. As the ensuing discussion will show, the Massachusetts Code had an indisputable influence on the codes of the neighboring colonies of Connecticut and New Haven enacted in 1650 and 1656 respectively. That influence is not surprising since the two Connecticut colonies were strongly Puritan and were founded by men who had been closely identified with the Massachusetts enterprise. ${ }^{11}$ The Connecticut government, in fact, was established under authority from Massachusetts, ${ }^{12}$ and examination of the Fundamental Orders adopted in Connecticut in 1639 reveals an essential identity between the systems of government obtaining in the two colonies. ${ }^{13}$ New Haven Colony, although independent of other colonies, adopted a form of government similar in its principal respects to that of Massachusetts and Connecticut. ${ }^{14}$

At the outset, it may be noted that the codes of Connecticut and New Haven are briefer and more condensed than that of Massachusetts. This was so chiefly because they contain few references to political matters, which had been dealt with earlier by various enactments of their respective general courts; ${ }^{15}$ moreover, a number of Massachusetts provisions were discarded in Connecticut as unsuitable to local conditions. On the whole, however, the Massachusetts influence is clear.

The Connecticut colonists had been aroused by the efforts of the Bay colonists to prepare the 1648 code, and in April, 1646, the General Court requested Roger Ludlow, former deputy governor, to draw up a code. ${ }^{16}$ That this was completed in 1650 is shown by a further reference, in the Connecticut Records on 5 February, 1650/51, to the effect that the code had been concluded and established in the previous May. ${ }^{17}$ The Connecticut Code of 1650 contains, in all, seventy-eight provisions, including the preamble. Of these, twenty-two provisions

10. See generally Haskins, De la codification du droit en Amérique du Nord au $x$ vii $^{\mathrm{e}}$ siècle, 23 Revue D'Hrstorre DU DroIT 311 (France 1955); Haskins, Codification of the Law in Colonial Massachusetts: $A$ Study in Comparative Laze, 30 IND. L.J. 1 (1954).

11. 1 OsGood, op. cit. supra note 1 , at $301-03,321$.

12. $I d$. at 303 .

13. $I d$. at 309-11.

14. Id. at 325 .

15. E.g., The Fundamental Orders of Connecticut.

16. 1 The Public Records of the Colony of Connecticut, 1636-1665, at 138 (Trumbull ed. 1850).

17. $I d$. at 216 . 
are practically the same as certain sections of the Massachusetts Code. ${ }^{18}$ The wording was copied so completely that it is clear that the Connecticut codifiers had before them a copy of the Massachusetts Code and did not hesitate to borrow freely from it. Thirty-six provisions of the Massachusetts Code were adopted with deletions ${ }^{19}$ or amendments. ${ }^{20}$ There are only twenty new topics in the Connecticut Code, ${ }^{21}$ but examination of these provisions shows that six had been included under other Massachusetts provisions, ${ }^{22}$ and all but a few of the remaining fourteen were concerned with purely local matters.

All in all, there was little departure from the pattern set by the Massachusetts Code. Although sixty-six provisions of that code were missing from the Connecticut Code, some of those related to governmental matters already provided for, and others were incorporated as parts of various sections of the Connecticut Code. ${ }^{23}$ That Connecticut did not strike out on its own, except for a half dozen of its seventy-eight provisions, is an indication both of the completeness and comprehensiveness of the earlier Massachusetts statute and of its suitability to the conditions of Puritan society elsewhere. By and large, Mr. Ludlow and his assistants were content to take the provisions of the Massachusetts Code, modify them where necessary, shorten them where wordy, and thus adapt them to the needs of the Connecticut Colony.

18. These twenty-two provisions are the Preamble, Ability, Age, Arrests, Ballast, Barratry, Burglary and Theft, Cruelty, Dammages pretended, Death untimely, Escheats, Fyre, Forgerie, Fornication, Idlenes, Inditements, Lands, freelands, Levyes, Manslaughter, Poore, Pound, pound breach, and Profane Swearing.

19. These are Actions, Cattel Cornfields Fences, Children, Constables, Conveyances fraudulent, Ecclesiasticall, Gaming, Lying, Magistrates, Straies, Wolves, and Wrecks of the Sea.

20. These are Attachments, Bills, Bounds of Townes and Persons, Capital Lawes, Cask \& Cooper, Fines, Hygh-wayes, Indians, In-keepers, Juries Jurors, Marriage, Masters Servants Labourers, Marshal, Militarie Affairs, Rates Fines, Records, Schools, Secretaire, Straies, Swyne, Tobacco, Trespasse, Votes, Watching and Weights \& Measures.

21. These twenty provisions are Cattle to bee Marked, Common Fields, Caveats Entred, Dissorder in Courte, Secreets in Courte, Delinquents, Execution uppon Delinquents, Fences, Guards at Meetings, Grand Jury, Ministers, Meintenance, Peage, Timber, Treasurer, Verdicts, Wyne and Strong Water, Vessells, Forreigners, and Home Lotts.

22. These six provisions are Cattle to be Marked, Common Fields, Fences, Grand Jury, Ministers Maintenance, and Wyne \& Strong Water.

23. These sixty-six provisions are Ana-Baptists, Appeale, Appearance Non-Appearance, Bakers, Benevolence, Bond Slavery, Causes Small causes, Charges publick, Clerk of Writs, Colledge, Condemned, Councill, Courts, Criminal causes, Deeds and writings, Deputies for the Generall Court, Distress, Dowries, Drovers, Elections, Farms, Fayrs \& Markets, Ferries, Fish Fishermen, Freemen Non-Freeman, Fugitives Strangers, Generall Court, Governour, Heresie, Hydes \& Skins, Jesuits, Impost, Impresses, Imprisonment, Justice, Leather, Liberties common, Mills Millers, Monopolies, Oaths Subscription, Oppression, Payments, Pipe-staves, Powder, Prescriptions, Prisoners Prisons, Protestation contra Remonstrance, Punishment, Replevin, Secresie, Ships Ship-masters, Strangers, Summons, Suits vexatious suits, Tile-earth, Torture, Townships, Treasure, Trespasse, Tryalls, Usurie, Wharfage, Wills intestate, Witnesses, Wood and Workmen. 
A similar process of adoption and adaptation can be seen in New Haven. There, an enactment of 1643 had established the structure of colonial government. ${ }^{24}$ However, this scheme was not made part of the code that New Haven later adopted, and it remained separate from the rest of the colony's law. When it was determined to collect the New Haven laws into one body, the General Court assigned the task to the governor. His use of the Massachusetts Code is made plain in the New Haven records. ${ }^{25}$ The New Haven Code was drawn up, approved and then sent to England to be printed in the fall of 1655. ${ }^{20}$ The completed code of 1656 contains only sixty-seven provisions, as contrasted with the one hundred and twenty-three sections of the Massachusetts Code; but in the heading of the New Haven Code specific acknowledgment is made to the Massachusetts laws, ${ }^{27}$ and their influence can be detected in the great majority of its provisions.

Twenty-seven sections of the Massachusetts provisions are contained in the New Haven Code, some of them combined with others. ${ }^{28}$. Twenty-nine of the New Haven provisions are modifications of Massachusetts provisions, ${ }^{29}$ and only thirteen are topics original to New Haven, ${ }^{30}$ although even some of these latter were included in the

24. Records of the Colony and Plantation at New Haven, 1638-1649, at 112-16 (Hoadley ed. 1857).

25. "The Gouernour being formerly desired by this court to view ouer the lawes of this jurisdiction, and draw up those of them which he thinkes will be most necessary to continew as lawes here, and compyle them together fitt to be printed, which being done, were now read, considered, and by vote confirmed, and ordered to be printed with the articles of confederation also, and the court further desired the gouernour to send for one of the new booke of lawes in the Massachusetts colony, and to view ouer a small booke of lawes newly come from England, which is said to be $\mathrm{Mr}$. Cottons, and to add to what is already done as he shall thinke fitt, and then the court will meete againe to confirme them, but in the meane time, [when they are finished] they desire the elders of the jurisdiction may have the sight of them for their approbation also." 2 RECORDS OF THE COLONY OR JURISDICTION OF NEW HAVEN, 1663-1665, at 146-47 (Hoadly ed. 1858).

26. $I d$. at 154 .

27. "Certaine Lawes, Liberties, and Orders, made, granted, and established, at severall times, by the Generall Court of New-haven Colony, for and to the Inhabitants of that Jurisdiction, now Collected, and further Published, for the use of such as are concerned in them, wherein they have made use of the Lawes published by the Honourable Colony of the Massachusetts." Id. at 571 .

28. These twenty-seven provisions are Age, Appearance Non-Appearance, Attachments, Bakers, Barratrie, Bills, Burglarie and Theft, Cask \& Cooper, Conveyances fraudulent, Damages pretended, Suits, Distresse, Dowries, Fyre, Fornication, Gaming, Imprisonment, Arrests, Inditements, Levies, Man-slaughter, Oppression, Pound Pound breach, Replevin, Straies, Trespasse, and Witnesses.

29. These twenty-nine provisions are the Preamble, Actions, Appeales, Ballast, Capitall Lawes, Cattell Corn Fields Fences, Charges publick, Childrens Education, Courts for Strangers, Ecclesiasticall Provisions, Escheates, Forgery or Falsifying, Heresie, Impost, Indians, Inkeepers Tipling Drunkenness, Leather and Shoo-makers, Lying, Magistrates, Marriage, Marshall, Masters and Servants \&c, Military Affairs, Rates Fines \&c, Records, Strangers Sojourners and Servants, Weights and Measures, Wills, and Wolves.

30. These thirteen provisions are Disturbers of the publick Peace, Divorce or a Marriage declared a Nullity, Horses, Incest, Laws without penalty, Mayning wounding, Plantations, Prophanation of the Lords Day, Seamen, Sentences of Judgment, Single persons, Strangers complaining, and Stripes. 
Massachusetts Code under other headings. New Haven, as well as Connecticut, failed to include sixty-five of the Massachusetts provisions, ${ }^{31}$ but these omissions do not mean that New Haven any more than Connecticut was making a fresh codification of New England law; the same reasons for omission already referred to apply to both colonies.

Thus, it is clear that the Connecticut and New Haven Codes drew primarily on the earlier Massachusetts legislation. However, the influence of the latter code did not end in New England. When, after the conquest of the Dutch, it was desired to frame a code of laws for the Province of New York, the New England codes were studied as precedents. ${ }^{32}$ In this way, substantive provisions of Massachusetts law spread southward to New York both directly and via Connecticut. Since, for a number of years, the Duke of York's laws were in effect in parts of New Jersey ${ }^{33}$ and Pennsylvania, ${ }^{34}$ the effects of the New England legislation went even further. Although this further spread of Massachusetts influence is beyond the scope of this paper, it is worth observing that, although the Massachusetts Code was framed to meet the conditions of Puritan society, many of its provisions were thought suitable to colonial conditions elsewhere. For example, among the important Massachusetts provisions which migrated southward to the Middle Atlantic colonies was that prescribing that, in intestacy, fee simple lands should descend equally to all children rather than to the eldest son by primogeniture as at common law. ${ }^{35}$ This basic rule of modern intestate distribution was thus in force in several localities well before Thomas Jefferson's attack on primogeniture in $1776 .^{36}$

31. These sixty-five provisions are Abilitie, Ana-Baptists, Benevolence, Bondslavery, Bounds of townes and persons, Causes small causes, Clerk of writs, Colledge, Condemned, Constables, Criminal causes. Crueltie, Death untimely, Deeds and Writings, Deputies for the Generall Court, Drovers, Elections, Farms, Fayrs \& Markets, Ferries, Fines, Fish, Freemen Non-Freeman, Fugitives Strangers, Generall Court, Governour, Hydes \& Skins, Hygh-wayes, Idlenes, Jesuits, Impresses, Juries Jurors, Justice, Lands Free lands, Liberties Common, Mills Millers, Monopolies, Oaths Subscription, Payments, Pipe-staves, Poor, Powder, Prescriptions, Prisoners Prisons, Protestation contra Remonstrance, Punishment, Schools, Secresie, Secretarie, Ships Ship-Masters, Summons, Swyne, Tile-earth, Tobacco, Torture, Townships, Treasure, Tryalls, Votes Usurie Watching, Wharfage, Wood, Workmen, and Wrecks of the Sea.

32. See GOEBEL \& NAUGHTON, op. cit. supra note 4.

33. See 23 NEW JERSEY ARCHIVES xiv-xv (1901).

34. See generally Loyd, Earry Courts of Pennsylvania 13 (1910); Charter

to William Penn and Laws of the Province of Pennsylvania iv (1879).

35. Massachusetts Colonial Laws 1660-1672, at 201, cl. 3 (Whitmore ed. 1889) ; 1 Delaware Body Laws 1700-1749, at 297, 298 (1752); 1 ColONial Laws of NEW York 9 (1891); 1 ACrs of Assembly of THE Province of Pennsylvania 33 (1775). These colonies all provided for a double portion to the eldest son, following the Massachusetts provision which appears to have been based on the Mosaic law as set forth in Deuteronomy: see DeUTERonomy XXI, at 17.

36. 1 JeFFERSON, WRITINGS 43, 139 (Washington ed. 1853). 
The foregoing demonstrates that detailed investigation of the legislation of the various American colonies can provide a fruitful source of information as to the means and extent of intercolonial legal borrowing. Supplemented by studies of local conditions affecting the acceptance or rejection of the legislation of a sister colony, such investigations can also shed much light on the patterns of life and thought in particular localities. 